OnLine Journal of Biological Sciences 12 (1): 6-10, 2012

ISSN 1608-4217

(C) 2012 Sowani and Thorat, This open access article is distributed under a Creative Commons Attribution

(CC-BY) 3.0 license

\title{
Antimicrobial Activity Studies of Bactoriocin Produced by Lactobacilli Isolates from Carrot Kanji
}

\author{
${ }^{1}$ Harshada M. Sowani and ${ }^{2}$ Prakash Thorat \\ ${ }^{1}$ Walchand Centre for Biotechnology, \\ Walchand College of Arts and Science, Solapur, MS, India \\ ${ }^{2}$ Department of Microbiology and Research Center,
}

Shri Shivaji Mahavidyalaya, Barshi-413 411 Dist-Solapur, MS, India

\begin{abstract}
Problem statement: In the present study, Staphylococcus aureus a causative agent of food poisoning is selected as a test organism to study the antimicrobial effect of bacteriocin. S. aureus produces number of exotoxins and enterotoxins which enters the body via contaminated food causing illness. Approach: In this case the use of antibiotics is one of the ways of treatment, but in addition to this if we advise such patients to consume the carrot kanji then it will cause better effect because carrot kanji is the naturally fermented food beverage consisting of microflora mainly the Lactobacilli. Results: The Lactobacilli have ability to produce antimicrobial compounds called bacteriocin. Isolation of bacteriocin was carried out from the naturally fermented carrot kanji. The bacteriocin produced by Lactobacilli was dialysed and used for the further studies. The well diffusion method is used to study the antimicrobial activity, effect of temperature, $\mathrm{pH}$, enzymes on bacteriocin. From the diameter of zone of inhibition the activity of bacteriocin was determined. The sensitivity of bacteriocin at different $\mathrm{pH}$ range showed that at neutral $\mathrm{pH}$ the diameter of inhibition zone was greater than that at alkaline as well as acidic $\mathrm{pH}$. Upto $100^{\circ} \mathrm{C}$ the bacteriocin activity was $80 \%$ but as temperature range increased upto $121^{\circ} \mathrm{C}$ it reduced sharply to $28 \%$. Conclusion/Recommendations: In addition to this the effect of alpha amylase, trypsin, catalase enzyme on bacteriocin activity was also studied which shows positive results with alpha amylase, reduced activity with trypsin and catalase remained unaffected.
\end{abstract}

Key words: Bacteriocin, Lactobacilli, Carrot Kanji, Staphylococcus aureus, antimicrobial activity, antimicrobial effect, alpha amylase, further studies, well diffusion method

\section{INTRODUCTION}

Lactobacilli are Gram positive, non spore forming, non motile, rod shaped, catalase lacking organisms occur in naturally fermented food and drink (Sahota $e t$ al., 2008; Karovicova and Kohaajdova, 2005). In northern India, carrots are processed in a special traditional way to prepare a ready to serve fermented drink which is deep purple in color known as Kanji (Ivanova et al., 2000; Joshi et al., 2006) Kanji production typically relies on spontaneous natural fermentation. It is nutritionally rich as it shows the presence of a viable microbiota that stimulate the growth of beneficial organisms within the gastrointestinal tract, have antimicrobial property (Berry et al., 1989; Sahota et al., 2008; Erten et al., 2008) The shelf life of kanji is about 7 days at $30^{\circ} \mathrm{C}$ during winters. For isolation of lactobacilli from carrot kanji MRS medium is used (De et al., 1960; Garrity,
2005). MRS medium was developed by De Man, et al. to to support luxuriant growth of all lactobacilli from oral, fecal, dairy and other sources lactobacilli. MRS medium contains peptones and dextrose which supply nitrogen and carbon. Tween 80, acetate, magnesium and manganese provide growth factors for culturing a variety of lactobacilli. These ingredients may inhibit the growth of some organisms other than lactobacilli. Lactobacilli, produce special antimicrobial compounds such as bacteriocins which are highly specific antibacterial proteins (Boris et al., 2001) prevents food spoilage and provides additional protection against Bacillus, Staphylococcus aureus and Clostridial spores in canned foods.

Most of the gram positive bacteriocins are a membrane active compound that increases the permeability of the cytoplasmic membrane. They often show a much broader spectrum of bactericidal activity than colicins. They fall within two broad classes, viz Corresponding Author: Harshada M. Sowani, Walchand Centre for Biotechnology, Walchand College of Arts and Science, Solapur, MS, India 
the lantibiotics and non lantibiotic (Jamuna and Jeevaratnam, 2004; Aly et al., 2006). Bacteriocin production in lactobacilli is growth associated, it usually occurs throughout the growth phase, maximum at logarithmic phase and ceases at the end of this phase (Narenderb et al., 2010; Joshi, et al., 2006) After production bacteriocin is characterized by determining its sensitivity towards different $\mathrm{pH}$ and temperature range (Nowroozi1 et al., 2004; Yildrim and Johnson, 1998; Boris et al., 2001) its protein content also measured (Lowry et al., 1951).

Present investigation, focused on the isolation of Lactobacilli from fermented carrot kanji, bacteriocin production and its antimicrobial activity on Staphylococcus aureus. Staphylococcus aureus an important pathogen causing food poisoning due to a combination of toxin-mediated virulence, invasiveness and antibiotic resistance (Marteau et al., 2001; Loir et al., 2003) The bacteriocin produced by lactobacilli isolated from kanji was used against Staphylococcus aureus. Bacteriocins are highly specific antibacterial proteins (Narenderb et al., 2010; Joshi et al., 2006) produced by strains of bacteria active mainly against some other strains of bacteria.

\section{MATERIALS AND METHODS}

Preparation of carrot kanji and Lactobacilli Isolation: Freshly harvested red colored carrots procured from local market were washed with clean water and peeled (Berry et al., 1989; Sahota et al., 2008). They were cut into small pieces $(3-4 \times 1 \mathrm{~cm})$ of equal size. Kanji was prepared using carrots (150 gm), common salt $(\mathrm{NaCl})(30 \mathrm{gm})$, mustard powder $(6 \mathrm{gm})$, chili powder (1.2 gm) and water 1 liter. The ingredients were mixed well and filled in sterile conical flask of $1000 \mathrm{~mL}$ capacity and the flask was cotton plugged. The spontaneous natural fermentation was carried out at $35^{\circ} \mathrm{C}$ for 4 days (Berry et al., 1989; Sahota et al., 2008) For isolation of lactobacilli De Man Rogosa Sharpe (MRS) medium (De et al., 1960) was used. The MRS medium contains peptone $(1 \mathrm{~g})$, yeast extract $(0.5 \mathrm{~g})$, meat extract $(1 \mathrm{~g})$, glucose $(2 \mathrm{~g})$, dipotassium hydrogen phosphate $(0.20 \mathrm{~g})$, triammonium citrate $(0.20)$, tween $80(0.1 \mathrm{~mL})$, magnesium sulphate $(0.20 \mathrm{~g})$, manganese sulphate (pinch), agar (2.5 g), distilled water $(100 \mathrm{~mL})$, $\mathrm{pH}(6)$ provides growth factors for culturing a variety of lactobacilli. The Lactobacilli are strict anaerobes, so after streaking, the MRS plates were incubated in the anaerobic jar at $37^{\circ} \mathrm{C}$ for $48 \mathrm{~h}$. The well isolated colonies on MRS agar were studied as per the tests given in the Bergey's manual of systematic bacteriology (Garrity, 2005).
Bacteriocin production and its partial purification: The bacteriocin producing strain was grown in $250 \mathrm{~mL}$ of MRS broth for at $37^{\circ} \mathrm{C}$ till it reaches to the late logarithmic phase by determining the O.D. at $660 \mathrm{~nm}$ (Boris et al., 2001) The cells were separated out by centrifuging broth for $15 \mathrm{~min}$ at $4^{\circ} \mathrm{C}$. To the supernatant which is used as bacteriocin, ammonium sulphate was added and about $40 \%$ saturation was achieved (Nowroozi et al., 2004; Yildrim and Johnson, 1998; Boris et al., 2001). After stirring on magnetic stirrer, it was kept undisturbed at $4{ }^{\circ} \mathrm{C}$ overnight. Precipitate formed was collected by centrifugation and dissolved in $20 \mathrm{mM}$ sodium phosphate buffer with $\mathrm{pH} 7$, dialyzed and used for the further studies as a partially purified Bactoriocin (Nowroozi1 et al., 2004; Joshi et al., 2006; Sivakumar and Saif, 2010).

Determination of Protein: Protein concentration of bacteriocin in supernatant was determined by the method of (Lowry et al., 1951), using bovine serum albumin as the standard (Lowry et al., 1951).

Antimicrobial effect of bacteriocin against Staphylococcus aureus: It was tested on nutrient agar, by well diffusion method (Nowroozil et al., 2004; Yildrim and Johnson, 1998) under aerobic condition. Prepoured nutrient agar plates were overlaid with $5 \mathrm{~mL}$ nutrient soft agar containing $0.2 \mathrm{~mL}$ of indicator cultures. Wells of size $5 \mathrm{~mm}$ diameter were cut off in the agar plate using a sterile borer and $50 \mu \mathrm{L}$ of the bacteriocin was placed in each well and kept in refrigerator for $1 \mathrm{~h}$ and thereafter incubate overnight at $37^{\circ} \mathrm{C}$. The plates were examined for zone of inhibition around the wells.

Effect of enzymes on bacteriocin activity: The above dialysed bacteriocin was incubated for $2 \mathrm{~h}$ in presence of 1 and $0.1 \mathrm{mg} \mathrm{mL}^{-1}$ of trypsin, alpha amylase and catalase respectively according to (Ivanova et al., 2000) Antimicrobial activity was recorded by using well diffusion method as described earlier.

\section{Characterization of bacteriocin:}

Sensitivity to $\mathbf{p H}$ and heat: To test the sensitivity to $\mathrm{pH} 5 \mathrm{~mL}$ aliquot of bacteriocin was taken in a test tube and the $\mathrm{pH}$ values of the contents were adjusted to $\mathrm{pH}$ range (2.0-8.0) individually, using $\mathrm{NaOH}$ or $\mathrm{HCl}$ and the activity was assayed as described earlier against staph. aureus by well diffusion method. To test heat sensitivity $5 \mathrm{~mL}$ aliquot of bacteriocin in different test tube was overlaid with paraffin oil to prevent evaporation and then heated at $60-120^{\circ} \mathrm{C}$ (in steps of $20^{\circ} \mathrm{C}$ ) for $10 \mathrm{~min}$. and these aliquot of respective temperature was tested against $S$. aureus by well 
diffusion method (Nowroozi1 et al., 2004; Karovicova and Kohaajdova, 2005).

\section{RESULTS}

From the fermented carrot kanji, lactobacilli were isolated. The well isolated predominant eleven isolates of lactobacilli (LB1-LB11) on MRS agar having different cultural morphology were picked up randomly and studied their morphological characters. The isolated colonies were colorless, flat and of irregular shaped and cell morphology showed small rods. All isolates showed gram positive nature and able to grow at $30^{\circ} \mathrm{C}$ and $50^{\circ} \mathrm{C}$ but unable to grow at $15^{\circ} \mathrm{C}$.

Further identification was carried by performing the biochemical tests and sugar fermentation pattern using current taxonomic status according to Bergey's manual of determinative classification system (Garrity, 2005).

All isolates showed acid production with Glucose, Fructose, Galactose, Maltose and Lactose fermentation while these isolates did not showed catalase activity and hydrolysis of starch and nitrate reduction. The results are summarised in Table 1.

As all the isolates showed the same characteristics and therefore we selected two isolates viz. LB1 and LB2 out of eleven for bacteriocin production and its antimicrobial activity studies. The antimicrobial activity of bacteriocin produced by isolates LB1, LB2 was determined against $S$. aureus. The diameter of inhibition zone for LB1 and LB2 was observed to be 25 and $18 \mathrm{~mm}$ respectively (Fig. 1).

Heat stability of bacteriocin by well diffusion method (Fig. 2) was studied by measuring diameter of inhibition zone at temperature $60 \mathrm{C}, 100 \mathrm{C}, 120^{\circ} \mathrm{C}$ (Table 2) and it showed $100 \%$ activity at $60^{\circ} \mathrm{C}$ for up to $10 \mathrm{~min}$ it remains stable and so if we considered this as $100 \%$ activity then at $100^{\circ} \mathrm{C}, 80 \%$ activity was observed. However after incubation for $10 \mathrm{~min}$ at $120^{\circ} \mathrm{C}$ under pressure, considerable decrease in the antimicrobial activity took place Fig. 2 (Table 2).

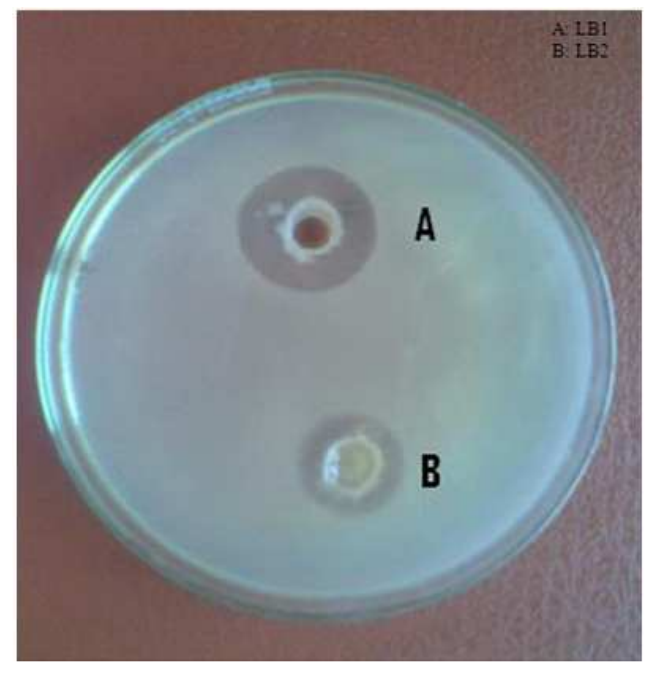

Fig.1: Zone of inhibition of $S$. aureus against bacteriocin produced by (A) LB1 and (B) LB2 by agar well diffusion method

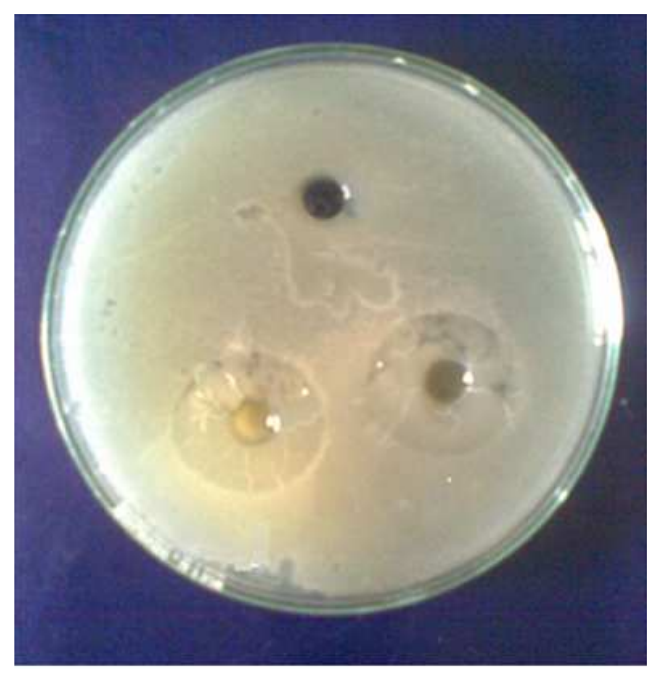

Fig. 2: Zone inhibition of Staphylococcus aureus against heat treated bacteriocin samples at (a) $60^{\circ} \mathrm{C}$ (b) $100^{\circ} \mathrm{C}$ (c) $120^{\circ} \mathrm{C}$

Table 1: Biochemical characterization of 11 lactobacilli isolate (LB) isolated from 4 days fermented carrot kanji

\begin{tabular}{|c|c|c|c|c|c|c|c|c|c|c|c|}
\hline Isolate code & LB1 & LB2 & LB3 & LB4 & LB5 & LB6 & LB7 & LB8 & LB9 & LB10 & LB11 \\
\hline Nitrate Reducti & - & - & - & - & - & - & - & - & - & - & - \\
\hline Catalase & - & - & - & - & - & - & - & - & - & - & - \\
\hline Glucose & + & + & + & + & + & + & + & + & + & + & + \\
\hline Fructose & + & + & + & + & + & + & + & + & + & + & + \\
\hline Galactose & + & + & + & + & + & + & + & + & + & + & + \\
\hline Sucrose & ++ & ++ & ++ & ++ & ++ & ++ & ++ & ++ & ++ & ++ & ++ \\
\hline Maltose & + & + & + & + & + & + & + & + & + & + & + \\
\hline Lactose & + & + & + & + & + & + & + & + & + & + & + \\
\hline Starch hyrolysis & + & + & + & + & + & + & + & + & + & + & + \\
\hline Genus identification & \multicolumn{11}{|c|}{ Lactobacilli spp } \\
\hline
\end{tabular}

Notation: (+) Acid production; $(+,+)$ Acid and gas production 


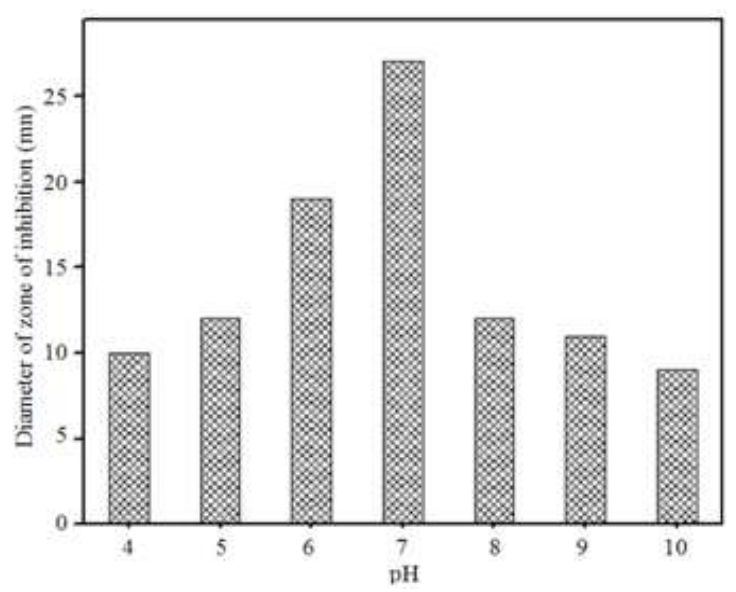

Fig. 3: Effect of $\mathrm{pH}$ on antimicrobial activity of bacteriocin

Table 2: Effect of temperature on antimicrobial activity of partially purified bacteriocin from isolated LB

\begin{tabular}{lr}
\hline Temperature $\left({ }^{\circ} \mathrm{C}\right)$ & Diameter of zong of inhibition $(\mathrm{mm})$ \\
\hline 60 & 25 \\
100 & 20 \\
121 & 7 \\
Control & 25 \\
\hline
\end{tabular}

As diameter of inhibition zone for LB1 was more, it is more active against $S$. aureus than LB2. Therefore, the bacteriocin produced by LB1 was taken to verify the heat stability.The effect of trypsin, catalase, alpha amylase enzyme on bacteriocin activity was studied. The effect of trypsin, catalase, alpha amylase enzyme on bacteriocin activity was studied.

Maximum activity of partially purified bacteriocin against S.aureus was noted at $\mathrm{pH} 7$ and if we consider this as $100 \%$ then at acidic $\mathrm{pH}(\mathrm{pH} 6) 80 \%$ activity was retained . But at alkaline $\mathrm{pH}$, the antimicrobial activity get highly reduced Fig. 3 .

\section{DISCUSSION}

As diameter of inhibition zone for LB1 was more, it is more active against $S$. aureus than LB2. Therefore, the bacteriocin produced by LB1 was taken to verify the heat stability.

The effect of trypsin, catalase, alpha amylase enzyme on bacteriocin activity was studied. Antimicrobial activity was reduced after treatment of dialysed bacteriocin sample with trypsin whereas treatment with catalase resulted in no activity change indicating that $\mathrm{H}_{2} \mathrm{O}_{2}$ was not responsible for inhibition. Treatment with alpha amylase resulted in increased diameter of zone of inhibition suggested that dialysed bacteriocin is glycosylated. This is in contrast to results obtained by Ivanova et al. (2000).

Heat stability of bacteriocin by well diffusion method (Ivanova et al., 2000) showed that it remains stable at $60^{\circ} \mathrm{C}$ for up to $10 \mathrm{~min}$ and so if we considered this as $100 \%$ activity then at $100^{\circ} \mathrm{C}, 80 \%$ activity was observed. However after incubation for $10 \mathrm{~min}$ at $120^{\circ} \mathrm{C}$ under pressure, considerable decrease in the antimicrobial activity took place. And $\mathrm{pH} 7$ showed maximum antibacterial activity.

\section{CONCLUSION}

MRS media seemed to be more suitable medium for lactobacilli isolation and bacteriocin production. The heat stability of bacteriocin indicates that it could be used as biopreservative in combination with thermal processing to preserve the food products. The activity of bacteriocin at pH 6 was noted $80 \%$ so it can be used in acidic foods like pickle, sausages and yogurt. It might be secondary metabolites. It would remain effective during food processing. Hence, the study revealed that bacteriocin from Lactibacillus species isolated from Lactibacillus species isolated from natural lactic fermentation of carrots possesses a wide spectrum of inhibitory activity against $S$. aureus so it has a potential application as a probiotic.

\section{REFERENCES}

Aly, S., O. Cheik, A.T. bassole H.N Imael, 2006. Bacteriocin and Lactic acid bacteria-a minireview Afr. J. Biotechnol., 15: 678-683.

Berry, S.K., J.K. Manan, G.J. Joshi, AK. Saxena and C.L. Kalra 1989. Preparation and evaluation of ready-to-serve (RTS) black carrot beverage (kanji). J. Food Sci. Technol., 26: 327-328.

Boris, S., R. Jimenez-Diaz, JL. Caso and C. Barbes, 2001. The partial characterization of a bacteriocin produced by a human Lactobacillus delbrueckii isolate with probiotic potential. J. Applied Microbiol., 91: 328333. PMID: 11473598

De, J.C., M.M. Rogosa and E.D. Sharpe, 1960. A medium for the cultivation of lactobacilli. J. Appl. Microbiol., 23: 130-135. DOI: 10.1111/j.13652672.1960.tb00188.x

Erten, H., H. Tanguler and A. Canbas, 2008. A Traditional Turkish Lactic acid fermented Beverage; Shalgam (salgam). Food Rev. Int., 24: 352-359. DOI: 10.1080/87559120802089324

Garrity, G., 2005. Bergey's Manual of Systematic Bacteriology: The Proteobacteria. 2nd Edn., Springer, New York, ISBN 0387950400, pp: 2816. 
Ivanova, I., P. Kabadjova, A.Pantev, S. Danova and X. Dousset, 2000. Detection, purification and partial characterization of a novel bacteriocin substance produced by Lactococcous lactis subsp. Lactis b 14 isolated from Boza-Bulgarian traditional cereal beverage. Biocatalogy, 41: 47-53.

Jamuna, M. and K. Jeevaratnam, 2004. Isolation and characterization of lactobacilli from some traditional fermented foods and evaluation of the bacteriocins: J. Gen. Applied Microbiol., 50: 79-90. PMID: 15248146

Joshi, V., S. Sharma and N. Rana, 2006. Production, purification, stability and efficacy of bacteriocin from isolates of natural lactic acid fermentation of vegetables. Food Technol. Biotechol., 44: 435-439.

Karovicova, J and Z. Kohaajdova, 2005. Lactic acid fermentation of various vegetable. Juices Acta Alimentaria Chem. Food Sci., 34: 237-246. DOI: 10.1556/AAlim

Loir, Y.L., F. Barnon and M. Gautier, 2003. Staphylococcus aureus and food poisoning. Genetics Mol. Res., 2: 63-76.

Lowry, O.H., N.J. Rosebrough, A.L. Farr and R.J. Randll, 1951. Protein measurement with the folinphenol reagent. J. Biol. Chem., 193: 265-275. PMID: 14907713
Marteau, P.R., D.V.M. Cellier and CJ. Schrezenmeir, 2001. J. Protection from gastrointestinal diseases with the use of probiotics. Am. J. Clin. Nutr., 73: 4305-4365.

Narenderb, R., P.A. Ravi, S. Sunder and V. Mallikarjun 2010. Isolation oand characterization of bacteriocin from fermrnted food and probiotics. Int. J. Pharma Biosci.

Nowroozi1, J., M .Mirzaii1 and M. Norouzi, 2004. Study of lactobacillus as probiotic bacteria. Iranian J. Publ. Health., 33: 1-7.

Sahota, P., G. Pandove, S. Jairath and G. Banta, 2008. A Functional probiotic beverage Kanji-Indian. J. Ecol., 35: 101-102.

Sivakumar, N. and R.A.B. Saif, 2010. Partial characterization of bacteriocins produced by Lactobacillus acidophilus and Pediococcus acidilactici. Braz. Arch. Biol. Technol. DOI: 10.1590/S1516-89132010000500023

Yildrim, Z. and M.G. Johnson, 1998. Detection and characterization of bacteriocin produced by Lactoccocus lactis subsp.cremoris R. isolated from radish. Lett. Applied Microbiol., 26: 297-304. PMID: 9633097 